\title{
LOCAL FACTORS INFLUENCING THE INCREASE IN DEVELOPMENT ACTIVITY IN SELECTED CITIES OF POLAND
}

\author{
Agata Antczak - Stępniak, M.Sc. \\ Department of Investment and Real Estate \\ Faculty of Economics and Sociology \\ University of Lodz \\ e-mail:agata.antczak@onet.eu
}

\begin{abstract}
Development activity in Poland began to increase in the 1990's as a result of market-oriented reforms, with the process continuing to this day. The beginnings were, however, not easy due to, among others, the absence of many important legal regulations and the lack of commercial financing. The situation changed in the second half of the 1990's, positively affecting residential development activity. The years 2008 - 2009 were particularly relevant in the course of the studied trend as a sharp increase in the number of completed developer-built residential dwelling units was recorded at this time. After this period, a decline in the number of dwelling units completed by developers was recorded, which indicates its strong dependence on changes in the economic environment. Fluctuations in the number of dwelling units completed by developers were also visible before Poland's accession to the European Union. This means that the diversity of development activity is influenced by many factors.

The available literature generally states that the growth of the real estate market depends on demand. Effective demand for real estate is understood as the number of people who are willing and financially able to buy or rent a particular kind of property at different prices, at a given time and in a given market. Therefore, it can be assumed that local factors have a particular impact on the growth of development activity. However, the question arises as to which of the many local factors are important to the growth of development activity and what factors can be used by local authorities to more effectively stimulate the growth of residential housing in their area.

The aim of the paper is to determine by means of econometric instruments the significance of the impact of individual local factors on development activity in the residential housing market in the largest cities of Poland.
\end{abstract}

Key words: development activity, development factors, quantitative analysis.

JEL Classification: C23, L74, R31.

Citation: Antczak - Stępniak A., 2015, Local Factors Influencing the Increase in Development Activity in Selected Cities of Poland, Real Estate Management and Valuation, Vol. 23, No. 3, pp. 73-84.

DOI: $10.1515 /$ remav-2015-0027

\section{Introduction}

In the 1990's, as a result of transformation of the political system, Poland's economy underwent numerous changes that completely transformed the housing construction sector. The structure of investors began to gradually change, the state started to withdrew from financing the sector, replaced by commercial banks, transformations in the sphere of production eliminated ineffective enterprises and, for example, large-panel technology. Private real estate development companies started to emerge, including companies financed by foreign funds. As a result, after more than two decades of 
growth, developers took over the part of the supply that in the 1990's was provided by housing cooperatives, employers or local authorities. Nowadays, this group of investors ranks second in terms of the number of completed residential dwelling units.

A sudden increase in the number of developer-built residential dwelling units was particularly notable in the years 2008-2009 due to the boom in the residential housing market which occurred in the years 2005-20071. After this period, an equally sharp decrease in development activity was recorded, caused not only by the bursting of the price bubble in the real estate market but also by the global economic crisis. It should be noted that even prior to Poland's accession to the European Union, fluctuations in the number of completed developer-built residential dwelling units were seen.

The possibilities of the growth of the real estate market to a large extent depend on effective demand, i.e. the number of people who are willing and financially able to buy or rent a particular kind of property at different prices, at a given time and in a given market. Therefore, it can be assumed that local factors have a particular impact on the growth of development activity. In addition to factors that influence real estate demand, one can point to a number of others that also have a significant impact, for example, administrative procedures or the development of infrastructure. This means that a number of various factors influence development activity, which in turn makes stimulating the growth of residential housing by local authorities difficult.

The aim of the paper is to determine the impact of local factors on development activity in the residential housing market in the largest cities in Poland by means of econometric instruments.

\section{Research Field Delimitation}

\subsection{Selection of analyzed factors - theoretical premises}

Development activity can be defined as business activity which consists of transforming the property so that its value rises (compare: ŚMIETANA, ZAGÓRSKA 2009, pp. 149-166; CADMAN, TOPPING 1995, p. 1). Property plays a particular role in the economy due to the fact that it may be an object of meeting residential needs, an object of investment, a source of income or a debt security (KUCHARSKA - STASIAK 2006, pp. 34-35). Developers seek to increase the value of property by its transformation, additionally creating supply in the market. Thus, since development activity seems to be closely linked with the real estate market and the development of entrepreneurship, it should be assumed that the growth dynamics of this activity are significantly influenced by determinants affecting the growth of the real estate market, as well as stimulants of entrepreneurship. Among the factors influencing the real estate market, the following are most commonly listed: the interest rate, the rate of inflation, the level of economic development, the unemployment rate, the wage level, as well as the number and structure of households (BOIRON, BOIRON 2008, pp. 24-25; NYKIEL 2011, pp. 59-72; CYRAN 2006, CHATURVEDI 2008 , p. 17). Legal determinants of the development of the real estate markets are mentioned less often (KUCHARSKA - STASIAK, SOPIŃSKI, WIŚNIEWSKA et al., 2000). Some authors distinguish and characterize factors that influence particular sides of the real estate market, i.e. supply and demand (compare: TAN, LIU 1998, pp. 76-78; WASSENBERG 2013, p. 116), while others group these factors according to the criterion of their spatial impact (compare: GRAZIOSI 2007, pp. 29-52). It is worth noting, however, that without demand for real estate, there will be no motivation for investing in it. The issues related to the development of entrepreneurship are slightly more complex, as it can be treated as a character feature or as a function (see: KOCHMAŃSKA 2008, pp. 29-38; LAZEAR 2005, pp. 649-680; ANTOCIC, BRATKOWIC, KREGAR, SINGH, DENOBle 2013). Certain authors, while discussing factors influencing the development of entrepreneurship, point to ones that determine the growth of business activity in a given area (compare: MINNITI, ZACHARAKIS, SPINELLI et al. 2007, p. 217; SATO, TABUCHI, YAMAMOTO 2012, pp. 1139-1166; CANEDO, STONE, BLACK, LUKASZEWSKI 2014, pp. 755-772).

In the framework of the existing knowledge and opinions, based on the review of the available literature, the author developed her own classification of factors that influence the growth of development activity in the residential housing market, which includes:

1) macro factors - which have a nationwide impact or an influence on a similarly significant system,

2) meso factors - which are characteristic of a given city, district or sector of development activity,

3) micro factors - which result from the specificity of a given developer or property.

1 The reaction on the supply side is lagged in relation to the demand side, due to the time-consuming and capitalintensive investment process. 
To date, factors that have a real impact on development activity in Poland have not been sufficiently explored. Foreign literature contains considerations regarding the impact of national as well as local factors on the growth of development activity in the residential housing sector (see: KAISER, WeISS 1967, pp. 232-249; ADAMS, LEISHMAN 2008; ESSAGHAH, IGHORUEMUFUA, OMATSONE, ОКОҮЕ 2013, pp. 6-16). In addition, studies have also been conducted on the character features of entrepreneurs specializing in construction and property development that determine their success (see: HUI, CSETE, RAFTERY 2006, pp. 228-245), as well as on the problems that developers encounter in Nigeria (see: ALIYU, KASIM, MARTIN 2011, pp. 263-268), or on factors that determine the selection of the location most conducive to the implementation of the venture (compare: SMERSH, SMITH, SCHWARZ 2003, pp. 61-74). Polish literature focuses mostly on the analysis of the impact of economic factors on development activity on the national level (see: GOSTKOWSKA - DRZEWICKA 2010, p. 50; KUCHARSKA STASIAK 2010, p. 105), or on the determinants of making investment decisions by developers (КОКОT 2012, pp. 53-69), which - it is worth pointing out - do not indicate the growth of development activity, as the investment can be a failure.

One of the features of the real estate market is its local character, particularly in relation to housing markets. This fact points to a significant impact of meso factors on the possibility of the growth of development activity. They may comprise various factors, depending on the location. Therefore, it may turn out that different factors will play a significant role in shaping development activity in particular markets (cities), or that the level of impact of the same factor will differ significantly. Hence, the paper is limited solely to an analysis of local factors that have an impact on the municipality level. These include:

1) demographic factors,

2) economic factors,

3) administrative and legal factors,

4) infrastructure and resource-related factors.

Their significance will be presented further in the paper.

\subsection{Selection of analyzed factors - practical premises}

The practical premises mentioned in the title of this section are associated with real possibilities of acquiring and processing source information necessary for the application of an econometric model in the study. The data for the model were acquired from the Local Data Bank and the annual report of the Central Bank of Poland on residential housing and commercial real estate in 2013. The data cover the years 2004-2013, with the exception of the following variables: "cena"(price) available since 2006 and "liczba_MPZP" (number of local land management plans), as well as "powierzchnia_objeta_MPZP" (area covered by local land management plans) available since 2007. The variables were analyzed for the cities that are the seats of voivodes (regional governments), with the exception of Gorzów Wielkopolski, which lacks data on prices though it is the seat of the voivode. As a result, Zielona Góra was featured in the study instead.

The number of completed developer-built residential dwelling units (y) in the years 2004-2013, based on the Local Data Bank of the Central Statistical Office of Poland, was chosen as the variable denoting the growth of development activity in Polish cities. The estimation covered $100 \%$ residential dwellings units for sale or rent and $4.06 \%$ of the total number of dwelling units completed in 2004, while in the years 2005 to $2013-100 \%$ of residential dwellings for sale or rent and $100 \%$ of individual dwelling units built for sale or rent ${ }^{2}$.

Due to the fact that some of the statistical data that quantify meso factors distinguished in the study are immeasurable and some have a limited time or territorial range, only the variables that are compatible in terms of time and space with the dependent variable were selected for further analyses.

The following were adopted as variables characterizing demographic factors that influence the possibility of the growth of development activity:

1) population (ludnosc) - measured as the real number of people in a given city,

\footnotetext{
2 According to the Construction Statistical Office, as well as opinions expressed in literature, developer-built residential dwelling units constructed by natural persons are included in the category "individual housing construction". There are, however, differences of opinion between authors in terms of their proportion (compare: KURLEJ, NOCKO, 2011; ŚMIETANA, ZAGÓRSKA 2009, pp. 149-166).
} 
2) working-age population (ludnosc_prod) - measured as the real number of people aged 18-65 in particular cities,

3) internal migrations (migracje_wewn) - measured as the net inter-district migration rate,

4) external migrations (migracje_zagr) - measured as the balance of foreign migrations,

5) birth rate (przyrost) - measured as the balance between births and deaths in a given city.

Taking into account the selection of factors comprising this group, it should be said that the correlation between the number of people or the birth rate and the number of completed residential dwelling units is quite obvious. A larger number of inhabitants increases the necessity for city growth. It seems necessary to draw attention to the number of working-age people as they are able to take on mortgages for the period of 30 years. Migrations also have an impact on the development of residential housing 3 , internal migrations, as well as external ones (especially migrations abroad).

Economic factors can also have a significant impact on the growth of development activity. The following variables characterize these factors:

1) the wage level (wynagrodzenie) - measured as the average monthly wage in PLN in a given city,

2) the level of unemployment (bezrobocie and stopa_bezrobocia) - measured as the actual number of people registered as unemployed and the unemployment rate,

3) prices of residential dwelling units (cena) - measured as the average transaction prices of $1 \mathrm{~m}^{2}$ of residential dwelling units in primary markets - using an average price carries a risk of the inappropriate reflection of prices characteristic of the particular local market by the average used. The hedonic index of prices may be a better indicator for this variable; however, due to the lack of detailed information about prices and characteristics of the real estate, its construction was impossible. Therefore, the author decided to use average prices in the study,

4) the level of competition in the construction market (konkurencja) - expressed as the real number of private entities registered in the National Official Business Register (REGON) in the division F CONSTRUCTION - due to the change in the manner of classification of business activity in the analyzed period of time, it is not possible to narrow down this category to the current division 41 which encompasses "construction work related to the erection of buildings".

Effective demand, i.e. the number of people who are willing and financially able to buy properties, is of real importance in the study of demand for real estate. Thus, the wage level is important for the analysis undertaken. There is no doubt that the higher the income of the population, the relatively greater the amount of money that people are willing to spend on buying a flat or a house. Higher incomes, therefore, encourage developers to initiate new investments. Demand for residential properties can be also analyzed in relation to the level of unemployment. In theory, the higher the unemployment rate in the city, the fewer people are able to purchase properties. Another economic factor contributing to the possibilities of the growth of development activity in particular cities are the prices of real estate. Theoretically, the higher the average price of a given good, the fewer people among potential buyers are willing to buy it. Lower demand can in turn result in a reduction in supply. In the case of prices in the housing market, however, the situation may be different. If the policy of banks granting loans is liberal, even with rising prices, demand can be high, as was the case in the years 2005-2007. If banks restrict their lending activities, then even relatively low prices will not result in an increase in demand. In previous years, the rise in prices caused by the swelling price bubble encouraged developers to carry out new investments, giving them hope for unusually high profit margins; therefore, one can expect a positive impact of prices on development activity during the analyzed period.

The level of competition (the number of entities in the construction market, including developers) and development ventures, completed as well as planned or under construction, pursued by developers also play a significant role in the growth of development activity. Developers need to take into account all these investments in creating their own projects. The more entities (developers) operate in a given market, the more residential dwelling units will be completed, which in turn means the competition for customers and problems with the sale of properties. On the other hand, the greater

\footnotetext{
3 The studies conducted in New Zealand indicate a close correlation between the net migration rate and the increase in the price of residential property. People immigrating into a given town seek a place of residence, which increases demand, which, under the conditions of limited supply, results in rising prices (McDonALD 2013, p. 2).
} 
the number of construction companies (contractors), the better the situation for the developer, due to the possibility of obtaining lower prices and a better quality of construction works.

The following variables reflect administrative and legal factors in the study:

1) the number of building permits (pozwolenia) - expressed as the total number of permits issued for the construction of new residential buildings,

2) the number of local spatial management plans (liczba_MPZP) - measured by the actual number of valid plans,

3) the area covered by the plans (powierzchnia_objeta_MPZP) - expressed as the area of the municipality (ha) for which valid local spatial management plans exist.

It is difficult to determine what percentage of all the permits issued constitute the permits granted to developers. The Local Data Bank provides only information on the total number of issued permits and permits issued for individual housing construction. An undeniable fact is that the more permits have been issued, the more buildings will be built. Local plans, in turn, provide transparency of municipality spatial planning, at the same accelerating the administrative process of obtaining a building permit. Regrettably, information on the plans has been available in the Local Data Bank only since 2007, which with the 2nd lag order results in reducing the time series to 5 periods. Nevertheless, they were included in the study as important.

The existing and planned, broadly defined, technical infrastructure is not without significanceto the success of developers' projects. Energy and water supply networks are essential even for small developers' projects so they can be cost-effective, and in the case of multi-family buildings, the sewage system is also important. In the case of small investments, one can use home sewage treatment plants or septic tanks with no outlet. It should also be remembered that every investment must have access to a public road. Consequently, the study also included the factors reflecting the saturation level of urban infrastructure expressed by the following variables:

1) road network (drogi) - measured as the number of kilometres of public municipal roads with paved or improved road surface per $1 \mathrm{~km}^{2}$ of the city area;

2) sewage system (kanalizacja) - measured as the ratio of the length of the sewerage network $(\mathrm{km})$ to the area of the city $\left(\mathrm{km}^{2}\right)$;

3) heating network (siec_cieplownicza) - measured as the ratio of the length of the transmission network $(\mathrm{km})$ to the area of the city $\left(\mathrm{km}^{2}\right)$;

4) water supply network (siec_wodociagowa) - measured as the ratio of the length of the distribution network $(\mathrm{km})$ to the area of the city $\left(\mathrm{km}^{2}\right)$.

The relationship between these variables and the number of completed residential dwellings seems to be obvious: the higher the saturation of the area with these networks, the better the investment availability of the land, which in turn should positively affect the number of dwelling units built.

In the presented group of factors, the existing real estate resources and the degree to which housing needs are met should also be taken into account. The following variables characterize these factors:

1) housing needs (zapotrzebowanie) - measured as the ratio of the number of people in a given city to the number of dwellings in housing resources,

2) actual floor area standard for the dwelling (powierzchnia_uzytowa) - determined as the average usable floor area per person in a given city,

3) volume of housing resources (zasoby) - the factor interpreted as the total number of dwelling units in the city, regardless of the legal status of the premises or the investor.

It is assumed that the greater the number of persons per one dwelling unit and the smaller the usable floor area per person, the greater the number of units completed in a given city should be in order to increase the quality of life of its residents. Moreover, the greater the volume of resources, the more likely that the demand for new dwelling units will be lower. The housing resources variable takes into account vacant dwellings.

In conclusion, it should be noted that the number of units completed in a given year by developers depends on the variables relating to this particular year only to a small extent. This is due to the fact that it is largely dependent on the conditions in which the decision to invest was taken or on the conditions in which the investment was initiated. Since, according to the data of Poland's Central Statistical Office, an average duration of the completion of residential dwelling units for sale or rent in the first quarter of 2014 was 23.7 months (Housing Construction ... 2014, p. 12), all the variables 
were delayed (lagged) by two time periods. Longer lags would have significantly limited the number of observations ${ }^{4}$.

\section{Research method - selection of the model estimation method}

Economics is considered a science that allows the modelling of social phenomena. An economic model allows us to eliminate the information that has little impact on the studied phenomenon (VARIAN 2005 , p. 31), which in the case of a large number of variables allows the identification of those that actually have a significant impact on development activity. Due to the short time series of variables (some have been available only since 2004 or even since 2007), to increase the number of observations, panel models were used in the study. Panel data are a subset of time and space data. They differ from the typical time and space data by the fact that they are characterized by a large number of objects and small number of periods. They allow to observe and explain the differences in the behavior of objects in different units of time, as well as different objects in a given period (DAŃSKA - BORSIAK 2011, pp. 711).

The heterogeneity of objects or time differences results from the diversity of the random component (random effects models) or the absolute term in relation to objects (fixed effects models). They are taken into account based on the assumption that the heterogeneity of the phenomenon is caused by non-observable factors or factors not covered in the model (DAŃSKA - BORSIAK 2011, pp. 13-40). It is assumed that fixed effects $(F E)$ are not random and are possible to estimate. In the models, they can express some specific characteristics of a given entity, for example, qualitative characteristics of business structure (KOROL, SZCZUCIŃSKI 2012, pp. 210-211), including the style of management, improved economy or innovativeness, as well as the willingness to invest or take risk (DoszYŃ, 2013, pp. 83-84). Random effects (RE) are not estimated, only their dispersion is determined, i.e. it is indicated which part of the random error results from unchanged over time and non-observable characteristics of given objects (KOROL, SZCZUCIŃSKI 2012, pp. 211-212).

To perform a regression analysis in the models based on panel data, GRETL software was used.

\section{Estimation results - statistical and economic evaluation of the results}

Typical real estate market analyses focus on selected variables that are chosen so as to characterize both the demand side and the supply side, as well as the balance between these two (FLOYD, ALLEN 2002, pp. 164-166). Development activity varies greatly. The number of factors that affect it allows two models to be built: the demand model and the supply one. The first model serves to identify important factors reflecting the demand for real estate built by developers - the greater the demand, the more willing they will be to expand their business in the selected area. The latter model - the supply one - should reflect the possibilities and determinants of the development of housing construction in particular cities.

\subsection{Demand model estimation}

The following variables were used in the demand model: ludnosc, ludnosc_prod, migracje_wewn, migracje_zagr, przyrost, wynagrodzenie, bezrobocie, stopa_bezrobocia, cena, zapotrzebowanie, powierzchnia_uzytkowa. The estimation of the panel model with the use of the classical least squares method (CLS) is possible if the condition is met that the CLS consistency estimator for overall error $\mathrm{E}$ $\left(v_{i t}\right)=0, \operatorname{Cov}\left(v_{i t}, x_{i t}\right)=0$ and for pure random error $E\left(\varepsilon_{i t}\right)=0, \operatorname{Cov}\left(\varepsilon_{i t}, x_{i t}\right)=0$, as well as there being no correlation between the individual effect and the explanatory variable (KUFEL 2011, pp. 173-181).

The first estimations, however, did not yield the expected results. As a result of intuitive elimination of variables containing similar information (different parameter signs), showing collinearity based on the variance inflation factor (VIF), as well as statistically insignificant variables, the final pooled-type model was obtained, estimated by the CLS method. Although diagnostic tests of the panel indicate the validity of CLS (the p-value for the Breusch - Pagan test is 0.0659403), the estimator is biased - it is characterized, among others, by a lack of normal distribution of residuals, as well as by the occurrence of positive autocorrelation.

Therefore, it was decided to estimate the panel model, taking into account the individual effect (random and fixed effects), which is a reflection of the specific characteristics of the particular units of

\footnotetext{
${ }^{4}$ GRETL treats the model as balanced, i.e. if there are any gaps associated with a variable, the software counts
} observations from the period in which all the variables are supplemented. 
the model, in this case - the cities. The estimation results of the fixed effects (FE) model are presented in Table 1.

Table 1

Demand model estimation with fixed effects, based on 96 observations

(16 units of cross-sectional data, time series $=6$ ); dependent variable: "mieszkania"

\begin{tabular}{|c|c|c|c|c|c|c|c|c|}
\hline & \multicolumn{2}{|c|}{ Coefficient } & \multicolumn{2}{|c|}{ Standard error } & t-distribution & \multicolumn{2}{|r|}{ p-value } & \\
\hline const & \multicolumn{2}{|c|}{-10220.1} & \multicolumn{2}{|c|}{5309.38} & -1.9249 & \multicolumn{2}{|r|}{0.05793} & * \\
\hline ludnosc_prod_2 & \multicolumn{2}{|c|}{0.0385705} & \multicolumn{2}{|c|}{0.0166549} & 2.3159 & & 0.02323 & ** \\
\hline migracje_wewn__2 & \multicolumn{2}{|c|}{1.09719} & \multicolumn{2}{|c|}{0.187353} & 5.8563 & \multicolumn{2}{|r|}{$<0.00001$} & $* * *$ \\
\hline cena_2 & \multicolumn{2}{|c|}{0.256648} & \multicolumn{2}{|c|}{0.152814} & 1.6795 & & 0.09711 & * \\
\hline \multicolumn{2}{|c|}{ Sum of squared residuals } & \multicolumn{2}{|c|}{64190527} & \multicolumn{4}{|c|}{ Residual standard error } & $\frac{1}{913.0406}$ \\
\hline \multicolumn{2}{|c|}{ LSDV R-squared } & \multicolumn{2}{|c|}{0.934039} & \multicolumn{2}{|c|}{ Within R-squared } & & \multicolumn{2}{|c|}{0.336246} \\
\hline \multicolumn{2}{|l|}{$\begin{array}{l}\text { Autocorrelation of } \\
\text { residuals- rho1 }\end{array}$} & \multicolumn{2}{|c|}{-0.176081} & \multicolumn{4}{|c|}{ Durbin-Watson statistic } & 2.159031 \\
\hline \multicolumn{2}{|l|}{ Chow test } & \multicolumn{7}{|c|}{$\begin{array}{c}\text { Test statistics: } F(15.77)=3.51837 \\
\text { with p-value }=P(F(15.77)>3.51837)=0.000137312\end{array}$} \\
\hline
\end{tabular}

Source: The author's own estimation.

The Chow test ${ }^{5}$ based on $\mathrm{F}$ statistics in the study indicates that group effects have a significant impact on the number of completed developer-built residential dwelling units. It seems obvious that the growth of development activity is dependent on the location - each city develops differently, some faster than others, for example Warsaw or Gdańsk; both of these cities are, among others, headquarters of many foreign companies. Better conditions for development, in turn, attract people who wish to improve their living conditions, and thus demand-encouraged developers carry out numerous new investments there. However, even though the panel model with fixed effects appears to be valid, for the sake of assurance the random effects model was also estimated (Table 2). It assumes that group effects are random.

Table 2

Demand model estimation with random effects, based on 96 observations (16 units of cross-sectional data, time series =6); dependent variable: "mieszkania"

\begin{tabular}{|l|c|c|c|c|l|}
\hline & Coefficient & Standard error & t-distribution & p-value & \\
\hline const & -2322.73 & 574.708 & -4.0416 & 0.00011 & $* * *$ \\
\hline ludnosc_prod_2 & 0.00584241 & 0.000922997 & 6.3298 & $<0.00001$ & $* * *$ \\
\hline migracje_wewn_2 & 0.87781 & 0.105674 & 8.3068 & $<0.00001$ & $* * *$ \\
\hline migracje_zagr_2 & -1.86416 & 0.690988 & -2.6978 & 0.00832 & $* * *$ \\
\hline cena_2 & 0.627945 & 0.140173 & 4.4798 & 0.00002 & $* * *$ \\
\hline Sum of squared residuals & \multicolumn{7}{|c|}{ Asymptotic test statistics: Chi-square(1) = 6.65226 } \\
\hline Breusch-Pagan test & \multicolumn{7}{|c|}{ Asymptotic test statistics: Chi-square(4) = 24.9517 } \\
with p-value = 5.14484e-005 \\
\hline
\end{tabular}

Source: The author's own estimation.

The low p-value of the Breusch - Pagan test implies the necessity of $\mathrm{H}_{0}$ rejection, hence it is reasonable to identify the part of the random component specific to individual objects. At the same time, the Hausman test ${ }^{6}$, as assumed, indicates that the estimator in the fixed effects model is consistent.

\footnotetext{
${ }^{5} \mathrm{H}_{0}$ in the Chow test assumes that the total impact of artificial variables is insignificant, hence isolating group effects is not justified. If the estimated $\mathrm{F}$ value is greater than the critical value, $\mathrm{H}_{0}$ is rejected - group effects have an impact on the shaping of the studied phenomenon (DAŃSKA-BORSIAK, 2012, p. 42.

${ }^{6} \mathrm{H}_{0}$ of the Hausman test assumes a lack of correlation between group effects and explanatory variables. If we assume the validity of the hypothesis, then the two models (the fixed effects and random effects ones) will be
} 
In contrast to the model made with the use of the CLS method, the value of Durbin - Watson in the FE panel model indicates a lack of autocorrelation of residuals $\left(d=2.159<4-d_{U}\right)$. This means that the forecast errors for the actual value of the "mieszkania" variable are randomly distributed. Regrettably, in each of the models estimated, the Doornik-Hansen test indicates a lack of normal distribution of residuals ( $p$-value $<0.05$ ). Literature stresses, however, that in studies of economic phenomena, empirical distributions rarely have a shape similar to the normal distribution. This is due to the fact that the impact of factors characterizing that which occurs in the economy is not uniform (LUSZNIEWICZ, SŁABY 2008, p. 120), there are various fluctuations - sharp spikes and drops. That was also the case in the present study - there was a price bubble and then a financial crisis. Nevertheless, the estimated fixed effects model has an economic interpretation. $\mathrm{R}^{2}$ denoting the degree to which the model function fits the empirical data indicates that it explains the growth of development activity, measured by the number of dwelling units completed, in approximately 93\%(KUFEL 2011, pp. 53-119; SOBCZYK 2013, pp. 62-70). It should also be noted that changes in the level of transaction prices in the primary markets, the number of working-age people and net inter-district migration rate in given cities in the studied period explain the phenomenon only in $33 \%$. The remaining part of the diversity of the number of completed dwellings results from the specific characteristics of each city.

The formula for the estimated demand model is as follows:

$$
\begin{aligned}
& \text { Mieszkania }=-10220.1+0.0385705 \text { ludnosc_prod_2 }+1.09719 \text { migracje_wewn_2 }+0.256648 \\
& \begin{array}{lllll}
\text { (p-value }) \quad(0.05793) & (0.02323) & (<0.00001)
\end{array}
\end{aligned}
$$

The impact of the variables on the number of dwelling units completed should be interpreted as unidirectional relationships. The increase in the working-age population, caused by baby boomers of the eighties taking up their first jobs, the rise in the number of people coming from the countryside to cities in search of employment and rising prices at the beginning of the studied period resulted in an increase in the number of residential dwelling units completed by developers two years later. The increase was not sharp as the development process is capital-intensive, hence the low values of the parameters. At the same time, a drop in demand caused by the price bubble burst in the following period and the beginning of the financial crisis resulted in a decline in the number of dwellings completed in subsequent periods. It would seem that a positive sign next to the "cena" variable is not correct as the price increase should theoretically lead to a decrease in demand for a given good. However, the years 2005-2007 were exceptional for the development of housing construction and the estimated model captures this phenomenon. The initial increase in demand caused by the liberal loan policy led to an increase in prices, however, over time the public - in fear of an even greater increase in prices - continued to buy dwellings. This meant that they reached very high values, which in turn encouraged developers to invest since they were able to achieve high margins due to that fact.

\subsection{Supply model estimation}

The following variables were used to estimate the supply model: konkurencja, pozwolenia, liczba_MPZP, powierzchnia_objeta_MPZP, drogi, kanalizacja, siec_cieplownicza, siec_wodociagowa, zasoby. As in the case of the demand model, the estimation of the supply model with the use of the CLS method did not produce the expected solutions. The Breusch - Pagan test indicated the need to consider the individual effect $(p=8.51237 e-008)$. Therefore, panel models with fixed effects (Table 3) and random effects (Table 4) were estimated, eliminating variables denoting similar information and statistically insignificant.

Table 3

Supply model estimation with fixed effects, based on 80 observations (16 units of cross-sectional data, time series = 5); dependent variable: "mieszkania"

\begin{tabular}{|l|c|c|c|c|l|}
\hline & Coefficient & Standard error & t-distribution & $p$-value & \\
\hline const & -493.442 & 531.89 & -0.9277 & 0.35715 & \\
\hline pozwolenia_2 & 7.9076 & 1.2991 & 6.0870 & $<0.00001$ & $* * *$ \\
\hline
\end{tabular}

consistent, the first one though will be ineffective. If the Hausman test statistics is greater than the chi-square critical value, then $\mathrm{H}_{0}$ should be rejected in favor of the alternative hypothesis that it is the fixed effects model which is valid (KUFEL 2011, pp. 174-175). 


\begin{tabular}{|c|c|c|c|c|c|}
\hline $\begin{array}{l}\text { powierzchnia_objeta } \\
\text { _MPZP_2 }\end{array}$ & 0.106305 & \multicolumn{2}{|c|}{0.0412754} & 2.5755 & ** \\
\hline Sum of squared residuals & \multicolumn{2}{|c|}{49849485} & \multicolumn{2}{|c|}{ Residual standard error } & 896.6738 \\
\hline LSDV R-squared & \multicolumn{2}{|c|}{0.933429} & \multicolumn{2}{|c|}{ Within R-squared } & 0.383290 \\
\hline $\begin{array}{l}\text { Autocorrelation of } \\
\text { residuals- rho1 }\end{array}$ & \multicolumn{2}{|c|}{-0.143779} & \multicolumn{2}{|c|}{ Durbin-Watson statistic } & 1.903146 \\
\hline Chow test & \multicolumn{5}{|c|}{$\begin{array}{c}\text { Test statistics: } F(15,62)=6.69626 \\
\text { with p-value }=P(F(15.62)>6.69626)=2.96477 \mathrm{e}-008\end{array}$} \\
\hline
\end{tabular}

Source: Author's own estimation.

Similarly to the demand model, the Chow test based on F statistics indicates the importance of the impact of group effects on the number of completed developer-built residential dwelling units. Also in this case, the validity of the model with fixed effects seems justified, however, to confirm it, the random effects model was estimated and the Hausman test statistics verified.

Table 4

Supply model estimation with random effects, based on 80 observations (16 units of cross-sectional data, time series $=5)$; dependent variable: "mieszkania"

\begin{tabular}{|c|c|c|c|c|c|c|}
\hline & \multicolumn{2}{|c|}{ Coefficient } & Standard error & t-distribution & p-value & \\
\hline const & \multicolumn{2}{|c|}{-1204.27} & 424.879 & -2.8344 & 0.00586 & $* * *$ \\
\hline pozwolenia_2 & \multicolumn{2}{|c|}{9.58401} & 0.834007 & 11.4915 & $<0.00001$ & $* * *$ \\
\hline $\begin{array}{l}\text { powierzchnia_objeta } \\
\text { _MPZP_2 }\end{array}$ & \multicolumn{2}{|c|}{0.151979} & 0.0326573 & 4.6538 & 0.00001 & $\star * * *$ \\
\hline \multicolumn{2}{|c|}{ Sum of squared residuals } & \multicolumn{2}{|c|}{\begin{tabular}{r|l|l|}
$1.36 \mathrm{e}+08$ & & Resi \\
\end{tabular}} & dal standard er & & 318.042 \\
\hline \multicolumn{2}{|c|}{ Breusch-Pagan test } & \multicolumn{5}{|c|}{$\begin{array}{c}\text { Asymptotic test statistics: } \text { Chi-square }(1)=38.141 \text { with p- } \\
\text { value }=6.58109 \mathrm{e}-010\end{array}$} \\
\hline \multicolumn{2}{|l|}{ Hausman test } & \multicolumn{5}{|c|}{$\begin{array}{c}\text { Asymptotic test statistics: } \text { Chi-square }(2)=3.40813 \\
\text { with p-value }=0.181943\end{array}$} \\
\hline
\end{tabular}

Source: Author's own estimation.

The Breusch-Pagan test also confirmed the validity of taking into account group effects in the estimation of the panel model. The Hausman test, however, indicates that the panel model with random effects is more effective in this case, although the residual standard error is much greater than in the fixed effects model. The variables which proved to be significant are the same as in the fixed effects model, and the values vary slightly. This raises the question where the discrepancy comes from since the dependent variable in both the demand and the supply model was the same. One may wonder whether it is an error in test estimation due to the lack of normal distribution of residuals, or whether, indeed, both models are valid. One should, therefore, answer the question of which type of group effects have a greater impact on the number of dwellings completed by developers: fixed or random ones. In the author's opinion - both types. Development activity is, in fact, very complex and spatially highly variable (Figure 1).

In some cities there are more developers doing business in the form of unlimited civil law partnerships or sole-proprietor businesses than in others. They differ in terms of company structure, therefore, fixed effects seem to be justified. It should be noted that the variations shown in Figure 1 can also result from the distance from the city to the western border, its location at transport hubs or at the seaside, as well as from the function of the city, e.g. as the capital, therefore random factors. Due to this fact, the supply model will be interpreted according to the Hausman test as the random effects model.

The formula for the estimated supply model is as follows:

$$
\underset{(p \text {-value })}{\operatorname{Miezkania}}=\underset{(0.00586)}{-1204.27}+\underset{(<0.00001)}{9.58401} \text { pozwolenia_2 }+\underset{(0.00001)}{0.151979} \text { powierzchnia_objeta_MPZP_2 }
$$

The estimated supply model thus indicates that the number of dwellings completed by developers depends on the number of building permits issued and the city's area covered by local plans lagged by two periods. Both relationships are unidirectional. An increase in the number of building permits 
issued by local authorities and in the area covered by local plans reflects pro-investment policies of the city, which favors developer growth. The parameter values, similarly to the demand model, present low values due to the capital-intensive investment process. It is difficult, however, to determine the extent to which the model explains the diversity of the studied phenomenon, as GRETL software does not show the level of the coefficient of determination $\mathrm{R}^{2}$ in the random effects model.

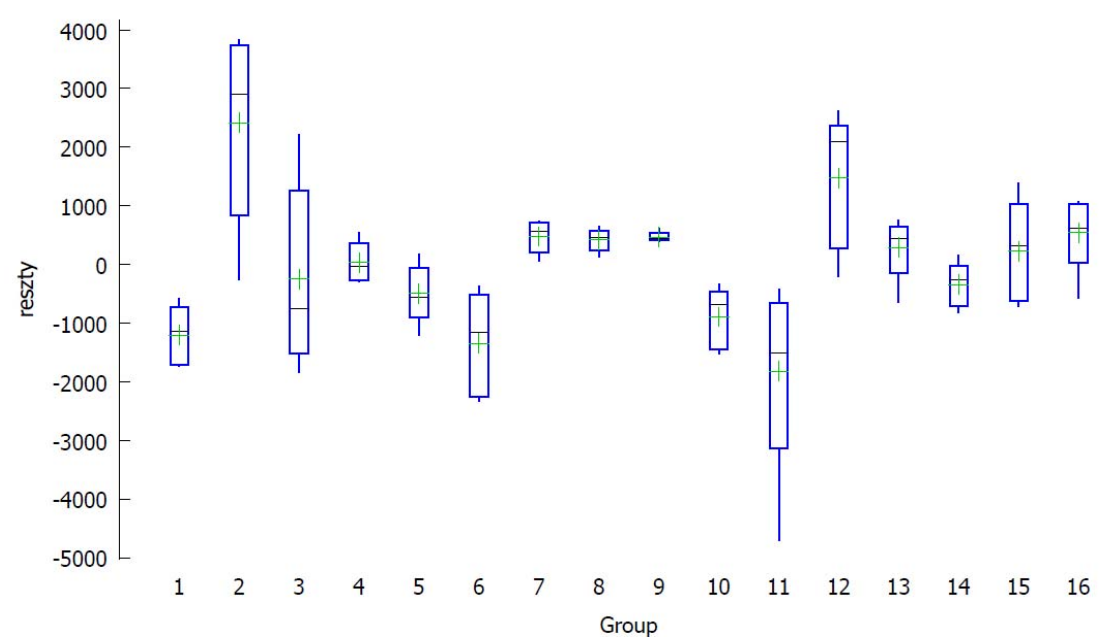

Fig. 1. Residuals of the regression equation of the number of completed developer-built residential dwelling units (random effects model). Source: The author's own compilation with the use of GRETL software.

\section{Conclusions}

To sum up, the statistical interpretations indicate that the parameters were estimated accurately. The direction of impact of the individual variables on the dependent variable is consistent with expectations, although particular attention should be paid to the "cena" variable. The analyzed period covers the years 2006-2007, hence the years when the price bubble in the real estate market occurred, which fostered development activity. In addition, it is worth noting that the development of two models - the demand and the supply model - allowed to obtain results which indicate that development activity depends not only on the analyzed factors but also on individual effects, manifesting as fixed and random effects, that local authorities often have little control over. The creation of one, complete model would not have allowed this fact to be captured.

On the basis of the above-presented study, as both models were based on the same dependent variable, one can attempt to answer the question of whether the demand-side factors (including the size of the working-age population, inter-district net migration rate and price) or the supply-side factors (the number of building permits and the city area covered by local plans) exert a greater influence on the growth of development activity. This assessment can be carried out based on the analysis of the determination coefficient, however, in the model including random effects, it was not estimated. Nevertheless, the value of standard errors of residuals can be compared. The demand model is definitely characterized by a smaller error, which would indicate a more significant impact of this type of factors on the number of completed developer-built residential dwelling units. In this case, the supply-side factors have an auxiliary role to play. This conclusion is consistent with the common belief that demand is the main driving force in the real estate market, also in the case of developers.

This means that the possibilities of stimulating development activity by local authorities are limited to the factors that can be observed and that change over time. In particular, in order to encourage developers to act, hence contribute to the economic growth in the area, local authorities ought to especially attract working-age people to the cities, e.g. by creating new jobs, as well as increase the city area covered by local plans, which would greatly facilitate investment processes.

It should be noted, however, that the study presented for publication is not complete and precise due to the limited time series of many variables. As a result, it is particularly difficult to analyze the Polish real estate market and development activity by means of quantitative methods. Thus, the studied relationships require further analyses in future time periods. 


\section{References}

ADAMs D., LeISHMAN C. 2008. Factors Affecting Build Out Rates, Department for Communities and Local Government, London

AliYu A.A., KASIM R., MARTIN D. 2011. Factors Affecting Housing Development in Makama Jahum Area of Bauchi Metropolis, Nigeria, International Journal of Trade, Economics and Finance, Vol. 2, No. 4.

Antocic B., BratKowic Kregar T., Singh G., DeNoble A.F. 2013. The Big Five Personality Entrepreneurship Relationship: Evidence from Slovenia, Journal of Small Business Management, doi: 10.1111/jsbm.12089

BOIRON P., BOIRON C. 2008. Commercial Real Estate Investing in Canada. The Complete Reference for Real Estate Professionals. John Wiley \& Sons, Mississauga.

Budownictwo mieszkaniowe - I kwartat 2014 r. (Housing Construction - I Quarter 2014), CSO, Warszawa 2014.

CADMAN D., Topping R. 1995. Property Development. Taylor \& Francis Group, London.

CANEDO J.C, STONE D.L., BLACK S.L., LUKASZEWSKI K.M. 2014. Individual Factors Affecting Entrepreneurship In Hispanics, Journal of Managerial Psychology, Vol. 29 Issue 6.

Chaturvedi M. 2008. Twenty One Year of Real Estate. Accommodation Times Pvt Ltd, Mumbai.

CYRAN R. 2006. Czynniki wplywające na rozwój rynku nieruchomości. (Factors Influencing the Development of the Real Estate Market). Nieruchomości C.H. BECK, 11 [99] November 2006.

DAŃSKA - BORSIAK B. 2011. Dynamiczne modele panelowe w badaniach ekonomicznych (Dynamic Panel Models in Economic Research), Wydawnictwo Uniwersytetu Łódzkiego, Łódź.

DosZYŃ M., 2013, Zastosowanie metod ekonometrycznych do badania heterogeniczności obiektów (The Use of Econometric Methods in the Study of Heterogeneity of Objects), Studia i Prace WNEiZ No. 31/2013 Vol. 1, Szczecin.

Essaghah A. E. , Ighoruemufua H. O. , OMAtsone E. M., OKoYe V. O. 2013. Factors Affecting Physical Development of Residential Layouts in Asaba Metropolitan Region of Delta State, Nigeria. Arts and Design Studies 15.

FloYd CH. F., Allen M. T. 2002. Real Estate Principles, Dearborn ${ }^{\mathrm{TM}}$ Real Estate Education, Chicago.

GOSTKOWSKA - DRZEWICKA M. 2010. Próba określenia wptywu czynników makroekonomicznych na rozwój mieszkaniowego rynku deweloperskiego w Trójmieście na tle Polski w latach 1995-2007 (An Attempt to Determine the Impact of Macroeconomic Factors on the Development of Residential Development Market in Tricity against the Entire Polish Background in the Years 1995-2007). Barometr Regionalny No. 1(19) 2010.

GRAZIOSI D. 2007. Be a Real Estate Millionaire: Secret Strategies for Lifetime Wealth Today. Vanguard Press, Philadelphia.

HuI S.K., CSETE J., RAFTERY J. 2006. Factors Involved in the Success of Hong Kong Construction Property Entrepreneurs, International Journal of Entrepreneurial Behavior \& Research, Vol. 12, Issue 4.

KAISER J. WeISs S. F. 1970. Local Public Policy and the Residential Development Process, Journal of the American Institute of Planners, Vol. 36, Issue 1, 1970.

KOCHMAŃSKA M. 2008, Czynniki sukcesu rozwoju przedsiębiorczości w zarządzaniu matymi i średnimi przedsiębiorstwami $w$ regionie matopolskim (Success Factors of Entrepreneurship Development in Managing Small and Medium-sized Enterprises in the Matopolskie Region), Oficyna Wydawnicza Humanitas, Sosnowiec.

КОКОТ S. 2012. Analiza zmian uwarunkowań podejmowania inwestycji deweloperskich w wybranych miastach Polski (An Analysis of Changes in Determinants of Making Development Investments in Selected Polish Cities), Studia i materiały Towarzystwa naukowego nieruchomości, Vol. 20, No. 1, Olsztyn.

KOROL J., SZCZUCIŃSKI P. 2012. Ekonometryczne modelowanie zróżnicowania zwiazków w sektorze małych $i$ średnich przedsiębiorstw w przestrzeni regionalnej (Econometric Modeling of Diversity of Relationships in the Sector of Small and Medium-sized Enterprises in the Regional Space), Studia i Prace Wydziału Nauk Ekonomicznych i Zarządzania/Uniwersytetu Szczecińskiego, Szczecin.

KUCHARSKA - STASIAK E. 2006. Nieruchomość w gospodarce rynkowej (Property in the Market Economy). PWN, Warszawa.

KUCHARSKA - STASIAK E. 2010, Uwarunkowania rozwoju dziatalności deweloperskiej w Polsce (Determinants of the Growth of Development Activity in Poland), Badania naukowe, Vol. 25, No. 2, Kielce 2010. 
KUCHARSKA - STASIAK E., SOPIŃSKI M., WIŚNIEWSKA E. ET AL. 2000. Uwarunkowania rozwoju rynku nieruchomości (Determinants of the Development of the Real Estate Market). Wydawnictwo Absolwent, Łódź.

KUFEL T. 2011. Ekonometria. Rozwiązywanie problemów z wykorzystaniem programu GRETL (Econometrics. Solving Problems with the Use of GRETL Programme). PWN, Warszawa.

KURLEj Z., NOCKO A. 2011. Budownictwo mieszkaniowe w Polsce wedtug form budownictwa w latach 20002010 (Housing Construction in Poland According to Types of Construction in the Years 2000-2010). Construction Statistics Centre, presentation at V Conference "The Construction Market and Prices in Research and Statistics".

LAZEAR E. P. 2005. Entrepreneurship. Journal of Labor Economics, Vol. 23, No. 4.

LUSZNIEWICZ A., SŁABY T. 2008. Statystyka z pakietem komputerowym Statistica PL. Teoria $i$ zastosowania (Statistics with Statistica PL Software. Theory and Applications.), C.H. BECK, Warszawa.

MCDONALD CH. 2013. Migration and the Housing Market, Reserve Bank of New Zealand, Analytical Notes, AN2013/10, December 2013.

MiNNITI, ZACHARAKIS, SPINELLI I INNI 2007, Entrepreneurship: The Engine of Growth, Praeger Publishers, Westport.

NYKIEL L. 2011. Demograficzne uwarunkowania rozwoju mieszkalnictwa i rynku mieszkaniowego (Demographic Determinants of the Development of Housing and the Housing Market). Studia i materiały Towarzystwa naukowego nieruchomości. Vol. 19 No. 3. Olsztyn.

SATO Y., TABUCHIAND T., YAMAMOTO K. 2012. Market Size and Entrepreneurship, Journal of Economic Geography 12 (2012), doi:10.1093/jeg/lbr035.

SOBCZYK M. 2012. Ekonometria (Econometrics). C.H. Beck, Warszawa.

Smersh G. T., Smith M. T.,. Schwartz JR. A. L. 2003. Factors Affecting Residential Property Development Patterns, JRER, Vol . 25, No. 1 - 2003.

ŚMIETANA K., ZAGÓRSKA E. 2009. Deweloper jako profesjonalny uczestnik rynku nieruchomości (Developer as a Professional Participant of the Real Estate Market), [in:] Henzel H. (ed.). Strategie inwestowania na rynku nieruchomości (Investment Strategies in the Real Estate Market). Wydawnictwo Akademii Ekonomicznej w Katowicach.

TAN J. T., LiU Y. 1998. Factors Affecting Housing Prices in Singapore, Jon D. Kendall, Donghyun Park (ed.), East Asian Economic Issues, Vol. 4, Word scientific Publishing Co. Pte. Ltd., Singapore.

WASSENBERG F. 2013. Large Housing Estates: Ideas, Rise, Fall and Recovery: The Bijlmermeer and beyond. IOS Press BV, Amsterdam.

VARIAN H. R. 2005. Mikroekonomia. Kurs średni - ujęcie nowoczesne (Intermediate Microeconomics - A Modern Approach). PWN, Warszawa. 